
МЕТОДИЧНОГОЗАБЕЗПЕЧЕННЯ ОСВІТНЬОГОПРОЦЕСУ (XIX - ПОчатОк ХХ ст.)

pozytsii Mykoly Shlemkevycha kriz pryzmu antropolohichnoi ustanovky [Mykola Shlemkevych's worldviews through the prism of anthropological attitude]. Scientific Bulletin of Lviv National University of Veterinary Medicine and Biotechnology named after S.Z. Hzhytskiy. Vol. 18, 2 (69), pp. 238-245. [in Ukrainian].

3. Vashchenko, H. (2006). Vykhovnyi ideal. T.1: pidruchnyk dlia pedahohiv, vykhovnykiv, molodi i batkiv. [Educational ideal. Volume 1: a textbook for teachers, educators, youth and parents]. Lviv, 278 p. [in Ukrainian].

4. Vyshnevskyi, O. (2006). Teoretychni osnovy suchasnoi ukrainskoi pedahohiky: posib. [Theoretical foundations of modern Ukrainian pedagogy: manual. for students. higher textbook lock]. Vol.2. Drohobych, 608 p. [in Ukrainian].

5. Lishchynska, O. (1998). Mykola Shlemkevych myslytel XX stolittia [Mykola Shlemkevych is a thinker of the 20th century]. Dzvin. No. 4. pp. 103-105. [in Ukrainian].

6. Lokatyr, N.M. (2018). Hromadsko-politychna ta naukova diialnist Mykoly Shlemkevycha (1894-1966 rr.)
[Locator NM Socio-political and scientific activity of Mykola Shlemkevych (1894-1966)]. Candidate's thesis. Vasyl Stefanyk Precarpathian National University. 249 p. [in Ukrainian].

7. Palamar, S. (2017). Problema formuvannia dukhovnomoralnykh tsinnostei studentiv $\mathrm{v}$ umovakh osvitnoho seredovyshcha [The problem of formation of spiritual and moral values of students in the educational environment]. Educational discourse, 3-4 (18-19), pp. 221-233. [in Ukrainian].

8. Rozdumy pro opravdannia zhyttia (peredova) (1961). [Reflections on the justification of life (advanced)]. Letters to Friends. Part. 3-4 (97-98). Niu-York - Toronto, pp. 13. [in Ukrainian].

9. Shlemkevych, M. (1961). Dyskusiia i pro dyskusiiu [Discussion and discussion]. Letters to Friends. Niu-Yok - Toronto, part. 3-4 (97-98), pp. 53-56. [in Ukrainian].

10. Shlemkevych, M. (1992). Zahublena ukrainska liudyna [The lost Ukrainian man]. Kyiv,168 p. [in Ukrainian].

Стаття надійшла до редакції 27.04.2021

УДК: 37.035.6:371

DOI:

Марія Багрій, кандидат філологічних наук, викладач вищої категорї Івано-Франківського фахового коледжу

ДВНЗ “Прикарпатський національний університет імені Василя Стефаника" Світлана Довбенко, кандидат педагогічних наук, доцент кафедри педагогіки початкової освіти

ДВНЗ “Прикарпатський національний університет імені Василя Стефаника"

\title{
РОЛЬ УКРАЇНСЬКИХ ПИСЬМЕННИКІВ ЗАХІДНОЇ УКРАЇНИ В РОЗВИТКУ НАВЧАЛЬНО-МЕТОДИЧНОГО ЗАБЕЗПЕЧЕННЯ ОСВІТНЬОГО ПРОЦЕСУ (XIX - початок XX ст.)
}

Стаття присвячена проблемі дослідження письменників-педагогів, на думку яких література мала знайти вираження у наповненні школи "національним духом" не тільки за формою, але й за змістом. Пріоритетним завданням школи в педагогічному прочесі стало виховання, а провідними принципами національного виховання вважалися народність, природовідповідність, гуманізація, демократизаиія. Цьому слугував насамперед добір тематичних творів, зазвичай історичної тематики, а також патріотично наснажених поетичних та прозових текстів, які “будили начіональні ідеі”. Ці догми варто із позичій сьогодення глибоко вивчити й проаналізувати, творчо застосовувати з урахуванням конкретної освітньо-педагогічної ситуачії.

Ключові слова: навчальна література; письменники - "будителі"; письменники-педагоги; наука; украӥнська література; "Руська трійщя"; О. Огоновський.

Jim. 10.

Mariya Bahriy, Ph.D.(Philology), Lecturer of the highest category, Ivano-Frankivsk Vocational College, SHEE "Vasyl Stefanyk Precarpathian National University"

Svitlana Dovbenko, Ph.D.(Pedagogy), Associate Professor of the Pedagogy of Primary Education Department SHEE "Vasyl Stefanyk Precarpathian National University"

\section{THE ROLE OF UKRAINIAN WRITERS OF WESTERN UKRAIN IN THE DEVELOPMENT OF EDUCATIONALAND METHODOLOGICAL SUPPORT OF EDUCATIONAL PROCESS (XIX - early XX century)}

The article is devoted to the problem of research of writers-teachers, according to whom literature should find expression in filling the school with "national spirit" not only in form but also in content. The priority task of 


\section{РОЛЬ УКРАЇНСЬКИХ ПИСЬМЕННИКІВ ЗАХІДНОЇ УКРАЇНИ В РОЗВИТКУ НАВЧАЛЬНО- МЕТОДИЧНОГОЗАБЕЗПЕЧЕННЯ ОСВІТНЬОГОПРОЦЕСУ (ХІХ- ПОчаток ХХ ст.)}

the school in the pedagogical process was education, and the leading principles of national education were considered to be nationality, conformity to nature, humanization, democratization. This was primarily due to the selection of thematic works, usually historical themes, as well as patriotic poetic and prose texts that "awakened national ideas".

In this aspect, we should note: the writers through the use of the terms "people", "nation", "Ukraine", "state" and similar concepts accustomed dormant people to such vocabulary, contributed to the spread of "Ukrainian", "Ukrainians" instead of "Rusyns", "Russian", raising to the level of national consciousness of the population of the region.

By placing the works of Ukrainian writers in textbooks for different types of schools, writers-teachers led to the suspension of the process of assimilation of Ukrainians, as schools usually used primers, reading books, textbooks, textbooks, dominated by works by Polish authors who raised children in love. According to the Polish-Lithuanian Commonwealth, Polishness was to be the basis for the education of citizens loyal to the Polish state, and this led to such a phenomenon as Mankurism.

Thus, as early as the middle of the 19th century, "awakeners" writers who held Ukrainophile positions created the first textbooks in Russian, as there was an urgent need for it, decisively broke with "paganism" and actively introduced Russian (Ukrainian) as the language of instruction. conclude the Ukrainian phonetic spelling.

Modern pedagogical education in Ukraine is focused on the formation of a teacher as a citizen-patriot, highly educated, harmoniously developed personality, who has pedagogical technologies, is capable of creative work, professional growth, is socially active. Therefore, many figures of Ukrainian writers who were teachers can serve as a great example of such a personality for a modern teacher.

It is quite natural that in recent years research has been intensified, which gives a scientifically sound description of the activities of teachers who contributed to the development of Ukrainian pedagogical thought and native education, promoted Ukrainian pedagogy as an organic component of national culture, worked on the national idea - education of Ukrainians.

Keywords: an educational literature; writers - "awakeners"; writers-teachers; science; Ukrainian literature, "Russian Trinity”; O. Ohonovskiy.

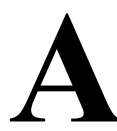

ктуальність статті. Не випадково в українській літературі, особливо Західної України, кінця XVIII - першої третини XX ст. витворився спеціальний педагогічний дискурс: багато літераторів у минулому описували системи виховання, зображали стан розвитку освіти, висловлювали свої педагогічні погляди. Центральною в педагогіці та літературі є концепція образу дитини, становлення людини як особистості, постать учителя, його місце і роль у шкільництві та суспільстві, його професіоналізм, особистісні якості й характеристики.

Постановка проблеми. Українські письменники Західної України початку XIX - 30-х рр. XX ст. увійшли в українську літературу не тільки як автори художніх творів, які вивчали учні в освітніх закладах різного типу: (народні школи, гімназії, учительські семінарії, університет), а й як укладачі навчальної літератури (букварів, читанок, хрестоматій, словників, підручників з історії літератури, літературознавства, мовознавства), популяризатори та дослідники творчості Тараса Шевченка, Юрія Федьковича та інших письменників.

До цього важливого освітнього наукового й педагогічного феномену вагомо спричинилися насамперед письменники-педагоги, які стояли на народницьких позиціях, обстоювали фонетичний правопис, мали педагогічну чи університетську освіту, працювали в гімназіях, учительських семінаріях, Львівському університеті. Завдяки своїй професії вони мали змогу вдосконалювати освітній процес, створювати якісне навчальнометодичне забезпечення (“на потребу дня”), виховувати юнацтво в національно-патріотичному дусі, будити любов до рідного народу.

Так, ще у середині XIX ст. письменники “будителі”, які стояли на українофільських позиціях, створюють перші підручники руською мовою, позаяк була в цьому нагальна потреба, “рішуче поривають 3 “язичієм" та активно вводять як мову навчання руську (українську), укладають український фонетичний правопис.

Аналіз останніх досліджень і публікацій. Окремі проблеми, пов'язані з розвитком історикопедагогічної науки, знайшли всебічне осмислення в сучасному науковому дискурсі Г. Бєлана, М. Галіва, Т. Завгородньої, В. Коновальчук, I. Розман, І. Стражнікової, О. Сухомлинської та ін.

Мета статті - проаналізувати внесок західноукраїнських письменників у розвиток навчально-методичного забезпечення освітнього процесу (XIX - початок XX ст.).

Виклад основного матеріалу. Наприкінці XIX ст. постають перші шкільні підручники для народних шкіл: граматики руської мови та читанки М. Шашкевича, Я. Головацького, О. Барвінського та ін., перші українські підручники для гімназій та вчительських семінарій, а також навчальна література для студентів, що вивчали руську словесність, історію та інші “науки”у Львівському університеті. 


\section{РОЛЬ УКРАЇНСЬКИХ ПИСЬМЕННИКІВ ЗАХІДНОЇ УКРАЇНИ В РОЗВИТКУ НАВЧАЛЬНО- МЕТОДИЧНОГОЗАБЕЗПЕЧЕННЯ ОСВІТНЬОГО ПРОЦЕСУ (ХІХ - Початок ХХ ст.)}

Визначне місце в розвитку прогресивної педагогічної думки Західної України першої половини XIX ст. належить Маркіянові Шашкевичу (1811-1843), Іванові Вагилевичу (1811-1866) та Якову Головацькому (1814-1888). Так, 1836 р.

М. Шашкевич опублікував брошуру “Азбука i Abecadlo" (1836), спрямовану проти спроб заведення в руській мові латинської абетки. Він написав першу в Україні "Читанку для малих дітей” (1850), яка була посмертно видана Я. Головацьким. Отож, слово “читанка” набуло широкого використання $[1,162]$.

Найважливіша праця Івана Вагилевича “ “Граматика малоруської мови в Галичині" (польською мовою). Він підготував дослідницьку працю “Розправи про мову південно-руську” (яка виявилася неопублікованою), де зробив спробу діалектологічного поділу української мови на “київські” і “галицькі” говірки [2]. 1862 р. як науковий керівник упорядкував Львівський міський (лонгерський) архів, підготував до друку близько 1200 документів з історії міста Львова і Галичини. До того, ж Іван Вагилевич не полишав своїх наукових занять і плідно співпрацював 3 Августом Бельовським на ниві історичної науки, передусім джерелознавства [2]. Писав також власні праці, що мають джерелознавче підгрунтя. Ця наукова спадщина I. Вагилевича потребує глибокого вивчення.

Спричинився I. Вагилевич до створення навчальної літератури для шкіл. Відомий як мовознавець i лексикограф: опублікував підручники "Граматика малоруської мови в Галичині” (1845) i “Початкові правила малоруської граматики” (1846); збирав матеріали до українсько-німецько-латинського словника, опублікував монографію про символіку в слов'янських народних піснях тощо.

Яків Головацький упродовж 1840-1841 pp. разом із братом Іваном видав у Відні збірку Григорія Ількевича "Галицькі приповідки і загадки”. Як академічний науковець (протягом 1848-1867 рр. був першим в історії Західної України професором “руської мови та словесності” (української мови та літератури) у Львівському університеті), зробив внесок у розвиток вищої університетської філологічної освіти. 1859 р. очолив боротьбу проти прихильників заміни кирилиці латинкою, що завершилася виданням у Львові німецькою мовою збірника "Питання мови і письма русинів в Галичині” (1861) [4, 215]. Певним чином відхід Я. Головацького на москвофільські позиції не міг не позначитися і на його наукових працях: “Граматика руского язика" (1851) далека від засад збереження і розвитку української мови. Варто зауважити, що письменник мав вплив на Миколу Устияновича, який також у своїх пізніх творах відмовився від народної української мови і перейшов на “язичіє" [3, 55].

Я. Головацького зараховуємо до когорти вчених-етнографів. Важливою $є$ праця “Етнографічна карта руського народонаселення в Галичині, північно-східній Угорщині і Буковині” (1875) як додаток до видання “Народные песни Галицкой и Угорской Руси”. За основу для неї Я. Головацький узяв найбільш грунтовну на той час “Етнографічну карту Австрійської монархії” К. Черніга 1855 р. До цього видання науковець уніс виправлення, замінивши польські, німецькі й угорські назви місцевостей на народні українські (руські), зрусифіковані назви. На карті видання позначено гідромережу, політичні й адміністративні кордони, залізниці, головні дороги, гори, міста і села, червоною фарбою підкреслено ті місцевості, де були записані Я. Головацьким народні пісні, або які згадуються у піснях. Адміністративні одиниці (округи і комітати) пронумеровані. Окремо на карті подано політикоадміністративний поділ Галичини й Угорщини 3 відповідним номером, що відповідає нумерації на карті. Способами якісного фону і ареалів зображено розселення шести народів, українців (у легенді - “русское населеніе") - зеленим кольором [5, 97]. Зазначеними вище науковометодичними працями Я. Головацького активно послуговувалися не одне покоління гімназистів, семінаристів та студентів.

Вагомий внесок здійснив Я. Головацький у філологічну, історичну, географічну науку, етнографію тощо як автор численних праць, що становили навчально-методичне забезпечення вивчення цих дисциплін у Львівському університеті та інших закладах середньої освіти. Так, з одного боку, досі зберігає свою наукову цінність низка історичних праць 3 дослідження окремих проблем історії Закарпаття, Галичини та Буковини, слов'янського етногенезу, польськогалицьких, польсько-українських і слов'яногерманських стосунків, статті про I. Котляревського, М. Шашкевича, I. Вагилевича, розвідки про “Слово о полку Ігоревім”, “Географический словарь западнославянских и южнославянских земель и прилежащих стран” (1877 р., виданий 1884 р.). 3 іншого боку, обгрунтування Я. Головацьким існування “одної руської народності і одної руської літератури” [5, 185] аж до виступів проти вживання української народної мови в літературі та науці мали негативний вплив на розвиток галицької та закарпатської інтелігенції [5] 


\section{РОЛЬ УКРАЇНСЬКИХ ПИСЬМЕННИКІВ ЗАХІДНОӤ УКРАЇНИ В РОЗВИТКУ НАВЧАЛЬНО-}

МЕТОДИЧНОГО ЗАБЕЗПЕЧЕННЯ ОСВІТНЬОГО ПРОЦЕСУ (ХІХ - ПочаТоК ХХ ст.)

Варто зазначити, що загалом перший у Західній Україні літературний альманах “Русалка Дністрова” (1837), який надрукований т. зв. гражданкою, виокремлювався 3 тогочасного літературного потоку, завдяки фонетичному правопису став близьким і зрозумілим для пересічного читача, окремі твори, опубліковані у збірці, згодом увійшли до навчальної літератури для народних шкіл, гімназій тощо $[8,54]$.

Студентом Я. Головацького (а відтак 31867 p. очільником кафедри руської філології Львівського університету після відходу Якова Головацького) був Омелян Огоновський (1833-1894) - випускник Львівського та Віденського університетів, майбутній громадський, освітній, науковий діяч (відомий учений-філолог), доктор філософії (1865) теолог, катехит при Домініканській (німецькій гімназії), викладач руської мови та літератури, релігії в Академічній гімназії м. Львова, декан філософського факультету Львівського університету (1877), професор цього університету (1888), членкореспондент Польської академії знань (з 1881 р.), один із засновників “Просвіти” (1868) (ії очільник 1877-1894), Народної Ради (1885) та Наукового товариства імені Т. Шевченка (1893) тощо.

Його мовознавчі та літературознавчі праці (одні 3 найбільш вагомих - “Студії в царині руської мови” (1880), “Граматика язика руського” (1889 р.), хрестоматії з історії церковнослов’янської мови” (1871), староукраїнської мови (1881), а також “Історія української літератури" залишилася незавершеною (публікувалась в “3орі” 1887-1894; видана окремо, тт. 1-6 (1887 р., 1889 р., 1891 р., 1893-1894 рр.) [6, 87]) мали велике значення для розвитку української науки та освіти. Зокрема, науковець наголошував на формуванні української літературної мови на засадах етимологічного правопису, чимало студентів під впливом його лекцій, праць (до слова, 3-поміж його студентів був Іван Франко, який неоднозначно відгукувався про викладацьку діяльність Омеляна Огоновського, однак підкреслював вартість його наукового доробку [10]), чимало юнаків змінювали свої погляди 3 виразно москвофільських на народовські.

Учений належить до реформаторів вищої освіти: О. Огоновський багато зусиль приклав до вдосконалення викладання руської мови та літератури, прагнув запровадити навчання у Львівському університеті живою мовою, замість “язичія" [7, 25]. Грунтовними дослідженнями творчості Тараса Шевченка (цикл статей “Критично-естетичний погляд на декотрі поезії Тараса Шевченка”, нарис “Життя Тараса Шевченка. Читанка для селян і міщан”, стаття
“Дещо про життя і літературну діяльність Т. Шевченка”, опублікована у перших двох томах “Кобзаря” за редакцією Омеляна Огоновського) науковець спричинився до популяризації творчості Тараса Шевченка, утвердження його культу 3поміж письменників Західної України, а також українців регіону.

Упродовж десятиріч учні гімназій та студенти Львівського університету навчалися за працею О. Огоновського "Історія літератури руської" (протягом 1887-1894 pр. побачило світ чотири томи (усього 6 частин). Учений пропонує власне бачення розвитку літературного процесу в Україні: перший том праці присвячений літературі від давньої доби до кінця XVIII, другий том - ліриці XIX сторіччя, третій - прозі XIX ст., четвертий етнографії цього століття. Таку наукову позицію (“систему зовсім неісторичну”) критикував I. Франко, зазначаючи, що за цього підходу “читач ... не одержує жодного уявлення про розвиток літератури") [9]. Значення цієї праці полягає і в тому, що митець обстоює право українського письменства на своє вагоме місце в колі світових літератур, аналізі епохи романтизму (більшість художніх творів О. Огоновського (балади, оповідання, поезії, зокрема, "Хрест”, драми “Федько Острозький”, "Настасія”, “Гальшка Острозька”) “цілком романтичні”).

Характерною особливістю науково-педагогічної діяльності українських письменників, публіцистів стало те, що навчальна література, яка вийшла 3під пера, була “змістовною” - слугувала формуванню національної свідомості молодої генерації українців. Ця мета, на думку письменників-педагогів, мала знайти вираження у наповненні школи “національним духом" не тільки за формою, але й за змістом.

Висновки та перспективи подальших досліджень. Отже, пріоритетним завданням школи в педагогічному процесі стало виховання, а провідними принципами національного виховання вважалися народність, природовідповідність, гуманізація, демократизація. Цьому слугував насамперед добір тематичних творів, зазвичай історичної тематики, а також патріотично наснажених поетичних та прозових текстів, які “будили національні ідеї.

У цьому аспекті зазначимо: саме письменники через уживання термінів “народ”, “нація”, “Україна”, “держава” та подібних понять призвичаювали приспаний люд до такої лексики, сприяли поширенню понять “український”, “українці” замість “русини”, “руський”, підносячи до рівня національної свідомості населення регіону. 


\section{РОЛЬ УКРАЇНСЬКИХ ПИСЬМЕННИКІВ ЗАХІДНОӤ УКРӒ̈НИ В РОЗВИТКУ НАВЧАЛЬНО- МЕТОДИЧНОГО ЗАБЕЗПЕЧЕННЯ ОСВІТНЬОГО ПРОЦЕСУ (XIX-пОчаТОК ХХ ст.)}

Уміщуючи твори українських письменників у навчальні посібники для різних типів шкіл, письменники-педагоги спричинилися до призупинення процесу асиміляції українців, позаяк у школах використовувалися зазвичай букварі, читанки, хрестоматії, підручники з літератури, де домінували твори польських авторів, які виховували дітей у дусі любові до Речі Посполитої, польськість мала бути підставою виховання відданих польській державі громадян, а це спричиняло таке явище, як манкурство.

Створене українськими письменниками навчально-методичне забезпечення, безумовно, не могло заповнити великої прогалини щодо україномовної навчальної літератури для дітей та юнацтва, однак стало помітним явищем у розвитку педагогічної думки Західної України та самобутнім літературним явищем у культурному й духовному просторі української інтелігенції. Воно грунтувалося на національній ідеї, окрім дидактичних функцій, утверджувало (особливо на початку XX ст.) державницькі ідеї, формувало громадсько-патріотичні цінності в дітей та юнацтва, виховувало християнські чесноти та стійкі морально-етичні почуття.

\section{ЛІТЕРАТУРА}

1. Довбищенко М. В. Політичні ідеї галицьких ідеологів національного відродження. Історія української політичної думки: навч. посіб. / М.І.Обушний, Т. С. Воропаєва, І. М. Грабовська та ін.; за заг. ред. М.І.Обушного. Київ: Видавничополіграфічний центр “Київський університет”, 2013. 479 с.

2. Євтух М. Розвиток освіти і педагогічної думки в Україні (кінець XVIII - перша половина XIX ст.) : дис. ... д-ра пед. наук у формі наук. доп. 13.00.01. Київ, 1996.70 с.

3. Єкельчик С. Українофіли: світ українських патріотів другої половини ХІХ століття. Київ: КІС, 2010. $272 \mathrm{c}$.

4. Історія педагогіки / за ред. М. Гриценка. Київ: Вища школа, $1973.447 \mathrm{c}$.

5. Лесюк М. Становлення і розвиток української літературної мови в Галичині. Івано-Франківськ: Місто $\mathrm{HB}, 2014.732 \mathrm{c}$.

6. Маланюк П. М. Освітні тенденції та виховні ідеали просвітницьких сподвижників Галичини. Тернопіль, $2000.160 \mathrm{c}$.

7. Микитюк В. Літературна і наукова спадщина Омеляна Огоновського: автореф. дис. ...канд. філ. наук. 10. 01. 03. Львів, 1995. 28 с.
8. "Русалка Дністрова" : документи і матеріали / АН УРСР ; Інс-т сусп. наук та ін. / [упоряд.: Стеблій Ф. І., Купчинський О. А., Грицак Я. Й., Парубій В. І., Полянський О. А.]. Київ : Наукова думка. 1989. 545 с.

9. Франко І. Іван Гушалевич. Франко I. Зібрання mворів: У 50 m. Т. 35. Київ: Наук. думка, 1982. С. 7-73.

10. Франко I. Перед збором руского жіночого товариства в Станиславові. Діло. 1884. Ч. 134.

\section{REFRERENCES}

1. Dovbyshchenko, M.V. (2013). Politychni ideyi halytskykh ideolohiv natsionalnoho vidrodzhennya [Political ideas of Galician ideologues of national revival]. History of Ukrainian political thought: textbook. way. I M.I. Obushny, T.S. Voropaeva, I.M. Grabovskaya and others; for general ed. M.I. Obushny. Kyiv, 479 p. [in Ukrainian].

2. Yevtukh, M.(1996). Rozvytok osvity i pedahohichnoyi dumky v Ukrayini (kinets XVIII - persha polovyna XIX st.) [Development of education and pedagogical thought in Ukraine (end of XVIII - first half of XIX century)]. Doctor's thesis. Kyiv, 70 p. [in Ukrainian].

3. Yekelchyk, S. (2010). Ukrayinofily: svit ukrayinskykh patriotiv druhoyi polovyny XIX stolittya. [Ukrainophiles: the world of Ukrainian patriots of the second half of the XIX century]. Kyiv, 272 p. [in Ukrainian].

4. Istoriya pedahohiky (1973). (Ed.) Gritsenko M. [History of pedagogy]. Kyiv, 447 p. [in Ukrainian].

5. Lesyuk, M. (2014). Stanovlennya i rozvytok ukrayinskoyi literaturnoyi movy v Halychyni [Formation and development of the Ukrainian literary language in Galicia]. Ivano-Frankivsk,732 p. [in Ukrainian].

6. Malanyuk, P.M. (2000). Osvitni tendentsiyi ta vykhovni idealy prosvitnytskykh spodvyzhnykiv Halychyny [Educational tendencies and educational ideals of educational associates of Galicia]. Ternopil, $160 \mathrm{p}$. [in Ukrainian].

7. Mykytyuk, V. (1995). Literaturna i naukova spadshchyna Omelyana Ohonovskoho [Literary and scientific heritage of Omelyan Ogonovsky]. Extended abstract of candidate's thesis. Lviv, 28 p. [in Ukrainian].

8. "Rusalka Dnistrova": dokumenty i materialy (1989).

["Mermaid of the Dniester": documents and materials / Academy of Sciences of the USSR; Inst. sciences, etc.] (Ed.). Stebliy F.I., Kupchynsky O.A., Hrytsak Y.Y., Parubiy V.I., Polyansky O.A. Kyiv, 545 p. [in Ukrainian].

9. Franko, I. (1982). Ivan Hushalevych [Ivan Gushalevich]. Franko I. Collection of works: In 50 vols. Vol. 35. Kyiv, pp. 7-73. [in Ukrainian].

10. Franko, I. (1884). Pered zborom ruskoho zhinochoho tovarystva v Stanyslavovi [Before the meeting of the Russian Women's Society in Stanislavov]. Work. p. 134. [in Ukrainian].

Стаття надійшла до редакції 11.05.2021

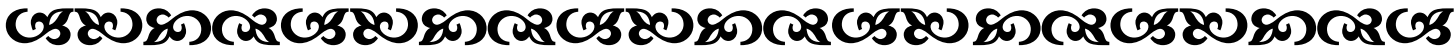

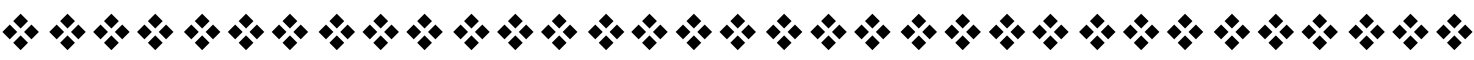

